\title{
KAJIAN TOKOH WAYANG GOLEK PURWA DAN PEMANFAATANNYA SEBAGAI BAHAN AJAR DALAM MENYAMPAIKAN PENGAJARAN SASTRA UNTUK MENINGKATKAN NILAI-NILAI BUDI PEKERTI PESERTA DIDIK
}

\author{
Aan Anjasmara \\ Universitas Kuningan \\ Jalan Cut Nyak Dien No. 36 A Cijoho Kuningan \\ Pos-el : aan.anjasmara@uniku.ac.id
}

\begin{abstract}
ABSTRAK
Bahan ajar merupakan bagian dalam pembelajaran yang memiliki peranan penting untuk menjawab tuntutan kurikulum. Bahan ajar yang dimaksud adalah bahan ajar pendidikan Bahasa Indonesia merupakan pintu masuk untuk mencapai permintaan Kompetensi Inti dan Kompetensi Dasar dalam kurikulum 2013. Seyogiyanya bahan ajar yang akan disampaikan kepada peserta didik merupakan bahan ajar yang dirancang oleh guru mata pelajaran yang dimaksud dengan memperhatikan tuntutan permintaan KI dan KD dalam kurikulum yang digunakan, dalam hal ini kurtilas. Ketepatan pembuatan bahan ajar sangat berperan sehingga permintaan dalam kurikulum bisa tercapai siswa pun dapat memahaminya dengan mudah. Hasil dalam penelitian ini penulis membuat modul yang dilengkapi RPP yang akan menjawab tuntutan KI dan KD, dalam hal ini KD 3.7, 4.7 dan 3.8,.4.8. materi di dalamnya menghadirkan contoh cerita wayang golek purwa. Hadirnya cerita wayang golek purwa dapat melestarikan khasanah kebudayaan Indonesia khususnya ditatar Jawa Barat. Disamping itu keberadaannya akan mudah diterima oleh peserta didik (peserta didik yang dimaksud yang berada ditatar Jawa Barat). Hadirnya bagah ajar yang disusun semoga dapat digunakan oleh guru untuk menyampaikan materi KD 3.7, 3.8, 4.7, dan 4.8 dengan mudah dan dapat dipahami oleh peserta didik, karena contoh yang disediakan cerita wayang golek purwa dapat dipakai dijenjang kelas X semester I.
\end{abstract}

Kata Kunci : wayang purwa, nilai budi, bahan ajar 


\section{PENDAHULUAN}

Pendidikan dan kurikulum adalah hal yang tidak dapat dipisahkan, pendidikan merupakan aplikasi dari cara melaksanakan pendidikan. Cara itu sendiri disebut kurikulum. Dalam UU No. 20 tahun 2003 dijelaskan tentang Sistem Pendidikan Nasional, bahwa kurikulum adalah seperangkat rencana dan pengaturan mengenai isi dan bahan pelajaran serta cara yang digunakan sebagai pedoman penyelenggaraan kegiatan mengajar. Kadang kita sukar membedakan antara kata pendidikan dengan pengajaran. Disini mari kita buat perbedaan, dalam kamus bahasa Indonesia kata mengajar dalam kamus bahasa Indonesia halaman 24 berasal dari kata ajar artinya petunjuk yg diberikan kepada orang supaya diketahui. Sementara kata mendidik masih dalam kamus bahasa Indonesia halaman 352 artinya memelihara dan memberi latihanmengenai akhlak dan kecerdasan pikiran.

Dari hal di atas jelas adanya bahwa mendidik lebih utama dari mengajar karena di dalamnya tidak hanya sebatas memberikan materi pelajaran, akan tetapi mengajak siswa untuk mengamalkan ilmu yang sudah didapatkannya.

Dalam Undang-Undang tentang Sistem Pendidikan Nasional bab 1 pasal 1, pendidikan adalah usaha sadar dan terencana untuk mewujudkan suasana belajar dan proses pembelajaran agar peserta didik secara aktif mengembangkan potensi dirinya untuk memiliki kekuatan spiritual keagamaan, pengendalian diri, kepribadian, kecerdasan, akhlak mulia, serta keterampilan yang diperlukan dirinya, masyarakat, bangsa dan negara.

Pendidikan dapat didapatkan dari siapa saja, bisa dari keluarga atau orang lain dilingkungan sosial sejalan dengan bertambahnya usia seseorang dari masa kanak-kanak, remaja, dewasa sampai orang tua. Permukaan akhir masa kanakkanak ditandai dengan masuknya anak ke kelas satu, hal yang wajib untuk anak di Amerika saat ini. Bagi sebagian besar anak, hal ini merupakan perubahan besar dalam pola kehidupan anak, juga bagi anak yang telah mengalami situasi pra sekolah (Hurlock:146). Seiring dengan perubahan yang sangat menentukan hendaknya pola mendidik harus tepat sehingga hasilnya akan sesuai dengan harapan.

Mengajar lebih cenderung mengandung makna, yaitu aktivitas mentransfer pengetahuan IPTEK yang dimiliki oleh guru kepada peserta didik agar peserta mengetahui, memahami, dan menguasai IPTEK sesuai kemampuan 
FON ; Jurnal Pendidikan Bahasa dan Sastra Indonesia

Volume 12 Nomor 1 Tahun 2018

yang dimiliki. Sedangkan mendidik ialah aktivitas mentranfer nilai, norma, adat istiadat, dan etika kepada anak didik agar mereka menjadi manusia yang mematuhi nilai, norma, dan etika yang berlaku di masyarakat, sehingga menjadi peserta didik yang berpengetahuan dan memiliki sikap dan prilaku yang baik (Hadis, Nurhayati, 2010:76).

Sementara Santrock dalam Psikologi Pendidikan (265) mengemukakan proses belajar atau pembelajaran adalah fokus utama dalam psikologi pendidikan. Ketika orang ditanya apa fungsi sekolah itu, mereka biasanya akan menjawab "Membantu murid untuk belajar."

Tujuan pendidikan, demikian pula tujuan matapelajaran dan satuan pelajaran lazim dirumuskan dari tiga aspek, yakni aspek kognitif, afektif, dan psikomotor (Nasution, 2012: 59).

Sementara tujuan kurikuler dan tujuan bidang studi atau matapelajaran termasuk tujuan umum pendidikan suatu lembaga pendidikan dan menggambarkan hasil belajar siswa yang paling umum sebagai hasil belajar yang diharapkan berkat proses belajar berkat proses belajar mengajar (Nasution, 2012:60).

Dari beberapa pengertian di atas penulis meyimpulkan bahwa pendidikan adalah proses terencana yang dilakukan oleh para pelaku pendidikan untuk mencapai tujuan pendidikan dengan memperhatikan proses jalannya pendidikan dengan serius dan sadar untuk mendapatkan hasil sesuai dengan harapan yang telah ditentukan. Pendidikan hendaknya mampu membentuk karakter seseorang, tentu perubahan karakter dari yang tidak baik menjadi baik.

$$
\text { Sebagaimana yang telah }
$$

dikemukakan di depan pendidikan bisa diartikan proses terencana yang dilakukan oleh para pelaku pendidikan untuk mencapai tujuan pendidikan dengan memperhatikan proses jalannya pendidikan dengan serius dan sadar untuk mendapatkan hasil sesuai dengan harapan yang telah ditentukan.

Karakter adalah mustika hidup yang membedakan manusia dengan binatang. Manusia tanpa karakter adalah manusia yang sudah "membinatang". Orang-orang yang berkarakter kuat dan baik secara individual maupun sosial ialah mereka yang memiliki akhlak, moral, dan budi pekerti yang baik (Zubaedi, 2013: 1).

Dari dua hal di atas Zubaedi dalam Desain Pendidikan Karakter (2013) mengemukakan bahwa pendidikan karakter adalah pendidikan budi pekerti plus yang intinya merupakan program pengajaran di sekolah yang bertujuan 
FON ; Jurnal Pendidikan Bahasa dan Sastra Indonesia

Volume 12 Nomor 1 Tahun 2018

mengembangkan watak dan tabiat siswa dengan cara menghayati nilai-nilai dan keyakinan masyarakat sebagai kekuatan moral dalam hidupnya melalui kejujuran, dapat dipercaya,disiplin, dan kerja sama yang menekankan ranah afektif (perasaan/sikap) tanpa meninggalkan ranah kognitif (berfikir rasional), dan ranah skill, (keterampilan, terampil mengolah data, mengemukakan pendapat, dan kerja sama).

Dari hal di atas dapat disimpulkan bahwa pendidikan karakter akan mampu melahirkan insan pendidikan yang memiliki karakter yang lebih baik. Ada banyak cara untuk merealisasikan pendidikan mampu membangun karakter baik dengan memasukan nilai-nilai budi pekerti dalam kegiatan pembelajaran. Salah satunya melalui pembelajaran sastra yang menitik beratkan pendidikan karakter. Karena pengertian sastra sendiri memiliki arti tulisan bahasa indah yang berisikan nilai-nilai budi pekerti. Sastra sendiri mengandung nilai-nilai yang melekat pada manusia, mulai dari sisi keindahan, imajinasi, sebagaimana manusia memiliki cipta, rasa, dan karsa. Kendatipun keberadaannya bukan fakta tapi hasil dari sebuah pengolahan sedemikian rupa imajinasi pengarang sehingga menjadi halus dan dituangkan dalam bentuk lisan atau tulisan untuk disampaikan kepada khalayak.

Sastra pada dasarnya akan mengungkapkan kejadian, namun kejadian tersebut bukanlah "fakta sesungguhnya", melainkan sebuah fakta mental pencipta. Pencipta sastra telah mengolah halus fakta obyektif menggunakan daya imajinasi, sehingga tercipta fakta mental imajinatif (Endraswara, 2013: 22).

Akan tetapi, justru yang terjadi di sekolah yang berhasil penulis kumpulkan informasinya melalui wawancara dengan beberapa guru terutama guru bahasa Indonesia, keberadaan sastra dalam kegiatan pembelajaran ternyata kurang mampu menjadi suntikan untuk mengubah atau memperbaiki budi pekerti ke arah yang lebih baik dari sebelumnya. Tentu banyak faktor yang menyebabkan terjadinya hal di atas, penyebabnya bisa dikarenakan contoh sastra yang dituangkan kurang begitu dekat dalam benak peserta didik. Sehingga nilai-nilai luhur yang terkadung dalam sastra kurang mendapat perhatian. Dari kenyatan di atas tentu sangat dibutuhkan terobosanterobosan baru untuk menyampaikan nilai-nilai budi pekerti peserta didik. Bahan ajar sendiri diartikan sebuah persoalan pokok yang tidak bisa dikesampingkan dalam satu kesatuan 
FON ; Jurnal Pendidikan Bahasa dan Sastra Indonesia

Volume 12 Nomor 1 Tahun 2018

pembahasaan yang utuh tentang cara harfiah berarti hurup, tulisan, atau pembuatan bahan ajar (Prastowo, 2015: karangan. Sementara dalam pengertian 16).

Dalam pembuatannya keberadaan kesusastraan lama istilah sastra berarti buku, baik yang berisi tentang dongeng, siswa harus diperhatikan, hendaknya pelajaran agama, sejarah, maupun disesuaikan dengan hal yang hangat dalam peraturan undang-undang. Kemudian pikiran siswa, contoh dan gambaran mendapat imbuhan gabungan ke-an disesuaikan dengan kondisi yang bisa diterima siswa. Pembelajaran seni musik mengenal lagu tentu kurang tepat jika siswa diperkenalkan dengan lagu jaman dulu, akan lain hasilnya kalau lagu yang dikenalkan kepada siswa judul lagu yang dikenal oleh peserta didik.

Para siswa harus dilibatkan sebagai rekanan yang penting dalam tugas tersebut. Ketika siswa berada dalam peranan kepemimpinan yang jelas, dan ketika semua siswa memiliki suara dan patokan dalam pendidikan karakter, orang dewasa akan menjadi jauh lebih efektif dalam mendorong karakter yang baik daripada yang dapat mereka lakukan sendiri (Lickona, 2013: 306).

Pembelajaran sastra dipandang menjadi kesusastraan yang berarti hal atau tentang buku-buku yang baik isinya dan indah bahasanya(Sugiantomas, 2010:7). Kandungan sastra dalam bahan ajar menjadi bagian penting untuk disajikan dalam rangka meningkatkan nilai-nilai budi pekerti yang dimaksud.

Wayang golek purwa dinilai penulis hal yang tepat dalam menyampaikannya. Disamping sebagai seni hiburan rakyat, keberadaannya juga masih mendapat tempat dihati masyarakat. Penulis meyakini wayang golek adalah hal yang melekat dibenak para pelajar terutama diwilayah Jawa Barat, karena kesenian ini adalah kesenian rakyat yang disukai semua kalangan dan usia.

Keberadaan wayang golek purwa oleh penulis merupakan hal yang tepat dalam menyampaikan nilai-nilai budi berdasarkan penelitian Wiryanaputra keberadaan wayang golek dikenal pada pekerti yang dimaksud, karena dalam sastra terdapat nilai-nilai baik yang bisa dijadikan pegangan manusia sebagaimana yang dikemukakan Sugiantomas dalam Teori Sastra (2010), istilah sastra secara masa bupati Bandung yang diangkat tanggal 20 Oktober 1794 yaitu Indrareja yang lebih dikenal dengan Adipati Wiranata Koesoema II kabupaten Citeureup/Dayeuh Kolot mengundang 
FON ; Jurnal Pendidikan Bahasa dan Sastra Indonesia

Volume 12 Nomor 1 Tahun 2018

dalang Ki Dipa Guna Permana, kemudian ia dipinta mengajarkannya dengan harapan di Bandung ada dalang yang menetap di kabupaten Bandung (Soepandi, 1988:32). Terbukti sampai saat ini pagelaran wayang golek purwa diminati masyarakat khususnya masyarakat Jawa Barat.

Setali tiga uang dengan hal di atas, cerita merupakan salah satu bentuk sastra yang memiliki keindahan dan kenikmatan tersendiri. Akan menyenangkan bagi anak-anak maupun orang dewasa, jika pengarang, pendongeng, dan penyimaknya sama-sama baik karena bisa didengar dan dibaca.

Cerita adalah salah satu bentuk sastra yang bisa dibaca atau hanya didengar oleh orang yang tidak bisa membaca (Aziz, 2008: 8). Disamping hal di atas hal ini juga menjadi dasar dari keingintahuan besar penulis tentang ihwal wayang golek purwa dan tokoh-tokoh di dalamnya serta kegelisahan penulis yang mengkhawatirkan hilangnya seni dan budaya warisan leluhur yang keberadaannya sudah diakui oleh dunia, serta keinginan penulis untuk melibatkan diri dalam memberikan penawaran untuk meningkatkan budi pekerti peserta didik dengan memperkenalkan tokoh wayang golek purwa dalam kegiatan pembelajaran sastra.

Terkait hal itu, penulis beranggapan seni wayang golek purwa akan mudah dikenal oleh peserta didik khususnya yang bearada diwilayah Jawa Barat, sehingga bisa dijadikan isi dalam membuat bahan ajar pendukung materi sastra dalam kegiatan pembelajaran.

\section{METODE PENELITIAN}

Metode yang digunakan dalam penelitian ini adalah metode penelitian kualitatif. Tahapan dari penelitian kualitatif adalah mengolah, menganalisis, menafsirkan data kualitatif setidaktidaknya pada lima bentuk kegiatan, yakni (a) Memvalidasi data, (b) mengorganisasi data, koding (coding data base), (c) menyajikan temuan, (d) menafsirkan makna temuan, dan (e) memvalidasi makna temuan.

Peneliti akan melakukan pengumpulan data dengan membuat catatan hasil observasi naskah atau wawancara dengan praktisi seni sunda wayang golek atau dalang, sehingga data yang didapatkan berupa catatan-catatan dari sumber yang didapatkan. Untuk mengumpulkan data peneliti akan melakukan beberapa langkah diantaranya 
FON ; Jurnal Pendidikan Bahasa dan Sastra Indonesia

Volume 12 Nomor 1 Tahun 2018

mengumpulkan populasi atau menentukan sampel.

\section{HASIL DAN PEMBAHASAN}

A. Nilai Budi Tokoh Yudistira

Dari uraian di atas indikasi kepribadian Yudistira sebagai berikut.

1. Moralitas (morality) hal ini dapat dilihat dari kutipan berikut. "anak ini akan menjadi orang yang paling suka kepada kebenaran dan kebajikan diantara semua manusia di dunia, namanya ialan Yudistira, yang kejayaannya akan menjadi buah bibir di tribawana (P. Lal, 2008:36).”

2. Menolong (altruism)hal ini dapat dilihat dari kutipan berikut. "Setibanya di kota, ia perintahkan mereka pulang ke rumah masingmasing dan memberikan hadiahhadiah hiburan kepada perempuanperempuan yang suami dan anaknya tewas dalam pertempuran. Dengan melakukan tindakan-tindakan baik yang terhitung banyak, ia memperoleh itikad baik dari perwiraperwira tentara dan kaula-kaulanya, dan berkah dari para Brahmin (P. Lal, 2008:368)."

3. Kemampuan bekerja sama (cooperatio)hal ini dapat dilihat dari kutipan berikut. Tuan tahu seluruh kisah hubungan-hubungan kita dengan Duryodana. Kami masih tetap Pandawa yang sama. Persahabatan masih tetap harapan kami. Tapi Indraprasta harus dikembalikan kepada kami. (P. Lal, 2008:197).”

4. Kerendahan hati (modesty) hal ini dapat dilihat dari kutipan berikut. "Yudistira memasuki keraton, Raja Wirata berpaling bertanya kepada para penasihatnya dan berkata, "Siapakah dia yang begitu tampan dan tegak lurus jalannya? Ia tidak mempunyai budak maupun kereta, ataupun gajah, namun ia tampak seperti Indra sendiri. (P.Lal, 2008:172)"

5. Simpatik (sympathy), hal ini dapat dilihat dari kutipan berikut. "Tidak. Berbuatlah seolah-olah kita tidak menduga apa-apa. Kalau Purocana mengira kita sudah mengetahui persengkolannya, ia akan bertindak lebih cepat. Duryodana licik. Biarkan dia membayangkan kita benar-benar sudah punah dimakan api; itu akan memberi waktu kepada kita untuk mempersiapkan diri menghadapi pengkhianatan berikutnya. Kita akan menggali lubang untuk meloloskan diri malam ini." (P. Lal, 2008:58).”

\section{B. Nilai Budi Tokoh Bima}


Dari uraian di atas indikasi kepribadian Bima sebagai berikut.

1. Minat berteman (friendliness), hal ini dapat dilihat dari kutipan berikut. Tapi Bima menghalanginya sambil berkata. "Berhenti! Mengapa kau persalahkan dia? Persalahkanlah Dewa Asmara, kalau kau ingin mempersalahkan seseorang, persalahkanlah aku, karena ku telah membangkitkan cinta dihatinya. (P.Lal 2008:60)

2. Minat berkelompok (gregariousness), hal ini dapat dilihat dari kutipan berikut. Bima yang tak kenal lelah dengan mudahnya mengangkat ibu dan keempat saudaranya untuk dipanggul dipundaknya, meneruskan perjalanan sampai akhirnya ia meletakan mereka yang sudah kehabisan tenaga untuk tidur ditempat terbuka di dalam hutan itu, dan ia sendiri tetap menjaga mereka.(P. Lal, 2008:59).”

3. Kemampuan asertif (assertiveness), hal ini dapat dilihat dari kutipan berikut. Tapi Bima menghalanginya sambil berkata. "Berhenti! Mengapa kau persalahkan dia? Persalahkanlah Dewa Asmara, kalau kau ingin mempersalahkan seseorang, persalahkanlah aku, karena ku telah membangkitkan cinta dihatinya. Tak boleh ada tangan yang berani mengangkat tangan kepada seorang perempuan didepanku, lawanlah aku!" Arimba menyerbunya; Bima menangkap lengannya dan menyeretnya sejauh sepuluh kaki di tanah seperti singa yang menyeret mangsanya. Arimba menggeramkesakitan dan Bima masih terus menyeretnya lebih jauh, khawatir kegaduhan itu akan membangunkan mereka yang sedang tidur. (P. Lal, 2008:60).

4. Tingkat aktivitas (activity-level), hal ini dapat dilihat dari kutipan berikut. Bima yang tak kenal lelah dengan mudahnya mengkat ibu dan keempat saudaranya untuk dipanggul dipundaknya, meneruskan perjalanan sampai akhirnya ia meletakan mereka yang sudah kehabisan tenaga utnuk tidur ditempat terbuka di dalam hutan itu, dan ia sendiri tetap menjaga mereka.(P. Lal, 2008:59).”

5. Mencari kesenangan (excitementseeking), hal ini dapat dilihat dari kutipan berikut. Apa gunanya terjun ke dalam peperangan kalau sekarang kakanda menolak untuk memikul beban kemenangan? Apa gunanya membunh Kurawa? Jika kami tahu 
FON ; Jurnal Pendidikan Bahasa dan Sastra Indonesia

Volume 12 Nomor 1 Tahun 2018

bahwa ini akan menjadi hasil dari daya upaya kami, kami takan pernah berperang. Apakah kakanda kira seorang ksatria tak mampu memaafkan, mengasihi, menaruh belas kasihan dan ahimsa? Jika moksa terdapat di dalam mengingkari kewajiban-kewajiban manusia, maka gunung-gunung dan pepohonan tentulah yang pertama akan dapat mencapai moksa! (P.Lal 2008:334)

6. Kebahagiaan (cheerfulness).hal ini dapat dilihat dari kutipan berikut. Lihatlah, dunia berputar karena kewajiban-kewajiban dilaksanakan sepanjang waktu. Bagaimanakah dengan melarikan diri dari melaksanakan kewajiban-kewajiban seseorang dapat memperoleh kebahagiaan?" (P. Lal, 2008:334).

\section{Nilai Budi Tokoh Arjuna}

Dari uraian di atas indikasi kepribadian Arjuna sebagai berikut.

1. Kemampuan imajinasi (imagination), hal ini dibuktikan dari kutipan berikut. Arjuna memilih sebatang panah yang menyeramkan dan berkata, "Semoga kau antarkan Karna ketempat bermukimnya Yama, Dewa Kematian,' Ia melepaskannya. Kepala Karna menggelinding ke bumi.”.
2. Emosionalitas (emotionality), hal ini dibuktikan dari kutipan berikut. "Mengapa kalian menampakan wajah sedih? Aku tidak melihat Abimanyu. Mengapa aku tidak melihat keceriaan di sini? Aku tahu Durna mengatur pasukan Kurawa dalam formasi kembang teratai, sejauh aku tahu tidak ada diantara kalian yang bisa menembus formasi itu. Apakah Abimanyu memaksa menjebol formasi itu? Jika benar demikian, ia pasti mati. Aku belum mengajarinya cara keluar dari formasi itu. Apakah benar ia tewas?...”Ya Hyang Widi, anaku terkasih telah menghadap Batara Yama. Yudistira, Bimasena, Dristadyumena, dan Satyaki, apakah kalian biarkan anak Subadra tewas ditangan musuh? (Rajagopalachari, 2013:340)

3. Intelektualitas (intellect), hal ini dibuktikan dari kutipan berikut. Dorna mengajarkan keterampilanketerampilan tambahan dan yang lebih unggul kepada Aswatama. Namun Arjuna mengetahui akal licik ini, dan mencari cara untuk mengisi pasunya lebih cepat. Kini ia dapat melakukan perjalanan yang sama cepatnya dengan Aswatama, sehingga 
pelajarannya bagaimanapun tidak kalah. (P.Lal, 2008:46)"

4. Kebebasan (liberalism). hal ini dibuktikan dari kutipan berikut. "Maya membungkukan badannya kepada Arjuna dan berkata "Karena tuan telah menyelamatkan hamba dari api yang mengerikan ini, katakan pada hamba apa yang Tuan inginkan agar hamba kerjakan." "Sudahlah, cukup bagiku bahwa kau bertanya,' jawab Arjuna. "Pergilah kemana kau suka. Bersikap ramahlah kepada semua orang," "Kenyataan bahwa kau mengatakan bahwa aku telah menyelamatkanmu sudah cukup merupakan hadiah bagiku." Arjuna mengulangi.(P.Lal, 2008:84)"

\section{Nilai Budi Tokoh Abimanyu}

Dari uraian di atas indikasi kepribadian Abimanyu sebagai berikut.

1. Kecukupan diri (self efficacy), hal ini dibuktikan dari kutipan berikut. "Abimanyu tersenyum dan menjawab:" Sahabatku, jangan khawatir aku adalah kemenakan Khrisna dan putra Arjuna. Bukankah itu sudah cukup untuk menjadi bekalku? Rasa takut tidak ada dalam kamusku. Kekuatan para musuh hanya seperempat kekuatanku. (Rajagopalachari, 2013:330).

2. Keteraturan (orderliness), hal ini dibuktikan dari kutipan berikut. Ayo, Pacu keretamu sekencangkencangnya kearah Durna jangan bimbang." Sais kerta itu melakukan seperti yang diperintahkan Abimanyu.Ketika kereta keemasan yang membawa dua pemuda yang gagah berani itu mendekat, pasukan Kurawa berseru:" Abimanyu menyerang! Abimanyu menyerang! Para Pandawa mengikuti dibelakang mereka!" Ketika kereta Abimanyu melaju kencang kearah mereka, pasukan Kurawa menjadi panik. (Rajagopalachari, 2013:330).”

3. Rasa tanggung jawab (dutifulness), hal ini dibuktikan dari kutipan berikut. Aku akan memenuhi harapan ayah dan paman. Kupertaruhkan keberanian dan nyawaku untuk kemenangan Pandawa." (Rajagopalachari, 2013:330).

4. Keinginan untuk berprestasi (achievement-striving), hal ini dibuktikan dari kutipan berikut. Mereka bingung tidak tahu apa yang harus dilakukan dan lari tunggang langgang tanpa mempedulikan perintah Durna. Yang mencoba 
bertahan, segera dihajar serangan Abimanyu, yang terus menyerang seperti api yang melahap hutan dimusim kemarau (Rajagopalachari, 2013:330).

5. Disiplin diri (self-disciplene), hal ini dibuktikan dari kutipan berikut. "Dengan tombak, Karna menerjang dan menyerang Abimanyu dengan hebat. Tapi salah satu panah Abimanyu berhasil menjatuhkan busur Karna. Kesempatan itu ia gunakan untuk memukul habishabisan Karna dan pasukannya. Mereka lari tunggang langgang menyelamatkan diri. Melihat semua itu, Pasukan Kurawa menjadi ketakutan.

\section{E. Nilai Budi Tokoh Duryodana}

Dari uraian di atas indikasi kepribadian Duryodana sebagai berikut.

1. Kecemasan (anxiety), hal ini dibuktikan dari kutipan berikut. "Dengan niat jahatnya ini, Duryodana memerintahkan membangun sebuah istana disuatu tempat yang indah bernama Parmanakoti di tepi Gangga, dan diisinya dengan segala permainan dan santapan yang enak-enak. Ia menamakannya "Istana Olah Raga Air”. Bendera-bendera yang cemerlang berkibaran di atasnya; santapan yang nikmat dimasak oleh juru masak yang ahli. (P. Lal, 1992:41).”

2. Kemarahan (anger), hal ini dibuktikan dari kutipan berikut. "Kami tahu dipihak mana kau, Widura," Kata Duryodana. "kau tak pernah menyukai kami, kami tak tahu kami mempunyai seekor ular dalam pangkuan kami. Kuperingatkan kau: Kami sudah merasa cukup mendengar gonggonganmu dan merasakan gigitanmu! Kau mirip seorang istri yang tidak suci-nyahlah, tinggalkan kami”. (P.Lal, 1992:107)

3. Depresi (depression), hal ini dibuktikan dari kutipan berikut.

4. Kurangnya kontrol diri (immoderation), hal ini dibuktikan dari kutipan berikut. "Selagi mereka terbenam dalam kesenangan, Duryodana mencampurkan racun yang sangat keras kedalam makanan untuk dimakan Bima. Dengan suara semanis madu tapi hati berisi sembilu, ia layani sendiri Bima, dan bersuka cita atas keberhasilan rencana jahatnya. Ketika Bima keluar dari kolam renang, ia mengeluh karena merasa capai (racun itu muali bekerja) dan berbaring untuk istirahat. Angin 
yang sejuk menyebarkan racun itu keseluruh bagian tubuh, lalu ia kehilangan kesadarannya. Duryodana mengikat dengan tambang yang terbuat dari rotan, dan membuangnya ke kali; disana Bima tenggelam dan hanyut sampai tiba di kerajaan dasar laut milik naga. (P. Lal, 1992:41)."

5. Kerapuhan (vulnerability), hal ini dibuktikan dari kutipan berikut. "Kau mempunyai teman, kereta, binatang. Aku sendiri tanpa senjata. Bagaimana aku akan dapat berperang melawan satu pasukan? (P.Lal, 1992:289)

\section{F. Nilai Budi Tokoh Utara}

Dari uraian di atas indikasi kepribadian Utara sebagai berikut.

1. Minat berteman (friendliness), hal ini dibuktikan dari kutipan berikut. "Siapa yang memukul dia, Ayahanda?" ia bertanya kepada Raja Wirata. "Kamilah yang memukulnya. Ia memuji-muji banci melebihi Anda." "Oh itu perbuatan yang mengerikan!" Kata Utara. "Mintalah maaf kepadanya sebelum Brahmin itu mengutuk Ayahanda." (P.Lal, 2008:190)"

2. Kemampuan asertif (assertiveness, hal ini dibuktikan dari kutipan berikut. "Ananda tidak merebut kembali ternak itu, Ayahanda, maupun mengusir para kurawa," kata Utara. "Putra seorang dewa menghentikan ananda ketika ananda melarikan diri dari medan perang, ia menaiki kereta ananda dan membunuh musuh. Ialah yang mengalahkan mereka. Dan ketika peperangan sudah dimenangkan, ia menghilang. Tapi ia akan kembali, entah esok entah lusa-siapa tahu?" (P.Lal, 2008:191)"

3. Tingkat aktivitas (activity-level), hal ini dibuktikan dari kutipan berikut.

4. Mencari kesenangan (excitementseeking), hal ini dibuktikan dari kutipan berikut. "Tapi ketika Utara melihat rombongan besar pasukan yang dipimpin Karna, Duryodana, Dorna, dan Aswatama berbaris didepannya, dan debu yang mengepul ke udara terinjak-injak oleh kaki, ia gemetar...dengan menyerahkan kehormatan dan kebanggaan, ia lempar ke samping busur dan anakanak panahnya (P.Lal, 2008:185)"

5. Kebahagiaan (cheerfulness). "Tapi ketika Utara melihat rombongan besar pasukan yang dipimpin Karna, Duryodana, Dorna, dan Aswatama berbaris didepannya, dan debu yang 
FON ; Jurnal Pendidikan Bahasa dan Sastra Indonesia

Volume 12 Nomor 1 Tahun 2018

mengepul ke udara terinjak-injak oleh kaki, ia gemetar...dengan menyerahkan kehormatan dan kebanggaan, ia lempar ke samping busur dan anak-anak panahnya (P.Lal, 2008:185)"

G. Nilai Budi Tokoh Semar Badranaya

Dari uraian di atas indikasi kepribadian Semar Badranaya sebagai berikut.

1. Moralitas (morality), hal ini dibuktikan dari kutipan berikut. "Sesudah anak-anaknya meninggalkan tempat, Semar kembali ketempatnya kemudian membersihkan diri terus masuk ke dalam ruangan, berdoa memohon supaya diberikan jalan keluar dalam menghadapi permasalahan yang tengah dialami Pandawa (Hamzah, 2006:58)"

2. Berprilaku menolong (altruism), hal ini dibuktikan dari kutipan berikut. "Karena Rupakanca dan Kancarupa tidak bisa mati walau sudah berdarah-darah oleh Bima, Semar berpikir bahwa bujukan Drupadi dapat membuka rahasiahnya walau dengan berpura-pura mau jadi permaisuri ketika dipinta oleh
Rupakanca, kalau rahasia sudah terbongkar dibalik kesaktian Rupakanca dan kancarupa selanjutnya tugas bima untuk menyelesaikannya. Begitu yang dipikirkan Semar. (Hamzah, 2006:98)"

3. Kemampuan bekerja sama (cooperatio), hal ini dibuktikan dari kutipan berikut. Semar berpikir bahwa bujukan Drupadi dapat membuka rahasiahnya walau dengan berpura-pura mau jadi permaisuri ketika dipinta oleh Rupakanca, kalau rahasia sudah terbongkar dibalik kesaktian Rupakanca dan kancarupa selanjutnya tugas bima untuk menyelesaikannya. Begitu yang dipikirkan Semar. (Hamzah, 2006:98)"

4. Kerendahan hati (modesty), hal ini dibuktikan dari kutipan berikut. "Semar tetap merendah dibalik pengetahuannya yang banyak (Hamzah, 2006:70)."

5. Simpatik (sympathy), hal ini dibuktikan dari kutipan berikut. "Semoga saja, kita berdoa bersama, biar saya dan anak-anak yang yang akan berangkat ke Sendang Panguripan" (Hamzah, 2006:70). 


\section{H. Nilai Budi Tokoh Sastrajingga atau Cepot}

Dari uraian di atas indikasi kepribadian Sastrajingga atau Cepot sebagai berikut.

1. Kemampuan imajinasi (imagination), hal ini dibuktikan dari kutipan berikut. "Hal itu merupakan sejarah jaman sekarang, bagaimana caranya menyelesaikan permasalahan sekarang, dasarnya apa? Ya kita berkaca kepada sejarah zaman dulu dong!" (Hamzah, 2006:59)"

2. Minat terhadap seni (artistic interest), hal ini dibuktikan dari kutipan berikut. "Cepot menirukan gaya seorang guru menerangkan materi pada murid-murid (Hamzah, 2006:59).”

3. Minat berpetualangan (adventurousness), hal ini dibuktikan dari kutipan berikut. "Cepot masih penasaran, karena tidak mungkin orang yang sudah mati dapat hidup kembali. Ia tetap mencari hal yang mencurigakan dalam kemah Rajamala (Hamzah, 2006:55)"

4. Intelektualitas (intellect), hal ini dibuktikan dari kutipan berikut. "Kalau semua penjaga sudah dalam keadaan mabuk, pasti penjagaan kemah akan bisa ditembus. Ini rencana yang akan dijalankan untuk bisa masuk ke dalam kemah musuh (Hamzah, 2006:55)"

\section{Nilai Budi Tokoh Dawala}

Dari uraian di atas indikasi kepribadian Dawala sebagai berikut.

1. Kemampuan asertif (assertiveness), hal ini dibuktikan dari kutipan berikut. "Dawala berpikir, sekuat apapun yang menghadapi orang yang hidup lagi setelah mati seperti Rajamala tentu lama-lama akan keteter dan kalah begitu kira-kira yang akan dialami Bilawa atau Bima (Hamzah, 2006:58)"

2. Tingkat aktivitas (activity-level), hal ini dibuktikan dari kutipan berikut. "Para penjaga kemah lengah, mereka bisa dipancing Dawala. Mereka tidak menaruh curiga bahwa minuman yang ditawarkan sudah dicampur dengan racikan khusus. Rasanya yang enak dan segar serta harum membuat para penjaga ketagihan. Tidak selang berapa lama para penjaga pingsan (Hamzah, 2006:55)"

3. Mencari kesenangan (excitementseeking), hal ini dibuktikan dari kutipan berikut. "Dawala 
FON ; Jurnal Pendidikan Bahasa dan Sastra Indonesia

Volume 12 Nomor 1 Tahun 2018

mengelilingi kemah dari dalam dan menyisirnya, kemudian ia menemukan barang yang mencurigakan. Begitu dibuka ternyata dibalik barang itu ada sebuah terowongan sebesar sumur (Hamzah, 2006;55)"

4. Kebahagiaan (cheerfulness), hal ini dibuktikan dari kutipan berikut. "Dawala mengelilingi kemah dari dalam dan menyisirnya, kemudian ia menemukan barang yang mencurigakan. Begitu dibuka ternyata dibalik barang itu ada sebuah terowongan sebesar sumur (Hamzah, 2006;55)".

\section{SIMPULAN}

Berdasarkan analisis data yang telah dilakukan, penulis menyimpulkan hal berikut.

1. Di tengah keberadaan wayang golek purwa yang terus melaju di tengah keadaan zaman semakin modern dan canggih, seni wayang golek purwa dalam praktiknya seorang dalang menceritakan cerita wayang golek purwa diawali dengan menyampaikan suluk yang dilantunkan dengan rumpaka atau patokan tersendiri sesuai dengan irama gamelan sunda. Isi dalam suluk yang dimaksud diantaranya menyampaikan bahwa wayang gerak digerakan oleh dalang, wayang merupakan lambang dari kehidupan manusia di alam dunia yang dihiasi dengan contoh bagi kehidupan manusia itu sendiri buah dari tulisan yang direka dengan bahasa indah. Tokoh-tokoh yang ada di dalamnya merupakan gambaran sifat dan karakter serta problematika manusia. Baik dan buruk, benar dan salah senantiasa dihadapi oleh manusia. Dari hal di atas penulis menyimpulkan keberadaan tokoh wayang golek purwa memiliki karakter yang hampir sama dengan karakter manusia karena wayang merupakan gambaran cerita kehidupan manusia.

2. Terkait cerita di dalamnya yang menceritakan tokoh yang tidak bisa terlepas dari cerita romantika kehidupan, bahagia, sengsara, susah, kecewa, amarah, sedih dan putus asa kerap dijumpai dalam penggalan cerita dimaksud. Romantika dimaksud sensntiasa selalu dihadapkan pada sebuah resiko yang tidak dapat dielakan. Hal ini mengajarkan kepada manusia bahwa pentingnya menanam kebaikan tanpa menimbang siapa yang diberi 
FON ; Jurnal Pendidikan Bahasa dan Sastra Indonesia

Volume 12 Nomor 1 Tahun 2018

kebaikan, tapi yang harus diyakini manusia adalah setiap perbuatan baik akan berbuah kebaikan, demikian pula sebaliknya. Dengan demikian penulis berpendapat bahwa cerita wayang golek purwa mengandung nilai-nilai budi pekerti yang bisa dijadikan pembelajaran bagi manusia.

3. Sastra atau susastra intinya tulisan indah yang memiliki pesan yang tersirat dalam sebuah karya sastra, baik puisi, cerpen ataupun novel. Kaitannya dengan keberadaan tokoh wayang golek purwa di dalamnya tersimpan contoh-contoh yang dapat dijadikan gambaran bagaimana seharusnya bertindak dalam kehidupan. Karena contoh buruk buahnya buruk demikian hasil dari baik itu kebaikan. Usia remaja pada masa SMA atau sederajat sudah dapat memahami nilai-nilai kehidupan sejalan dengan pengalamannya, keberadaan wayang golek juga dapat dipahamibterutama bagi siswa yang berada di tatar pasundan. Dari hal di atas penulis menyimpulkan keberadaan wayang golek purwa dapat dimanfaatkan dalam pembelajaran sastra untuk meningkatkan budi pekerti peserta didik terutama jenjang SMA.

\section{DAFTAR PUSTAKA}

Abimanyu Petir. (2014). Ajaran-Ajaran Emas Ramayana-Mahabarata. Jogjakarta: Laksana.

Achchari

Rajagopal.(2014).Mahabhbharata dan Ramayana.Jogyakarta:DIPTA.

Adi A.S. (2011). Mengenal Karya Seni Rupa Nusantara. Tangerang: CITRALAB.

Aminudin.(2015).Pengantar Apresiasi Karya Sastra.Bandung:Sinar baru Algensindo.

Aziz Abdul.(2008).Mendidik Dengan Cerita.Bandung:Rosda.

Cindo Morena. (2010). Aneka Wayang Nusantara. Jakarta: Multi kreasi Satudelapan.

Darma, Budi. (2007). Bahasa Sastra dan Budi Darma. Surabaya: JP Books.

Depdiknas. (2005).Pedoman Penulisan Buku Pelajaran bhasa dan Sastra Indonesia.Jakarta: Pusat Perbukuan.

Dewan Redaksi ESI.(2007).Ensiklopedi SASTRA Indonesia.Bandung: Titian Ilmu.

Dwiloka Bambang, Riana Rati.(2005).Teknik Menulis karya Ilmiah.Jakarta: Rineka Cipta. 
FON ; Jurnal Pendidikan Bahasa dan Sastra Indonesia

Volume 12 Nomor 1 Tahun 2018

Emzir dan Rohman Saifur.(2015).Teori dan Pengajaran Sastra.Jakarta:Raja Grafindo Persada.

Endaswara, Suwardi.(2013).Metodologi Penelitian Sastra.Jakarta:CAPS (Centre for Academic Publishing Service).

Gorys Keraf. 2010.Diksi dan Gaya Bahasa. Jakarta: Gramedia Pustaka Utama.

Hadis, Abdul dan Nurhayati.(2008). Psikologi Pendidikan.

Bandung:ALFABETA.

Hamzah

Jojo.(2013).Wirata

Geger.Kuningan:Silalatu

Harsrinuksmo Bambang dkk, (1999).

Ensiklopedi Wayang Indonesia.

Jakarta: SENAWANGI.

Heryadi, Dedi. (2010). Metode Penelitian

Pendidikan Bahasa. Bandung:

Pustaka Billah.

Indriyanti. (2010). Pengembangan Modul

(Makalah disampaikan pada

Pelatihan Pembuatan Modul bagi

Guru SMP se-Surakarta). Surakarta:

LPPM Universitas Sebelas Maret.

Jaenudin Ujam.(2012).Psikologi

Kepribadian.Bandung:

$\mathrm{CV}$ PUSTAKA SETIA

Karim, Mariana. (1980). Pemilihan

Pengajaran. Jakarta: Penlok P3G
Lal P.

(2010).Mahabharata.Jakarta:Grafik a Mardi Yuana

Lickona

Thomas.(2013).Character

Matters.Jakarta:Bumi Aksara.

Majid, Abdul. (2006). Perencanaan Pembelajaran. Bandung: PT. Remaja Rosdakarya.

Minderop Albertine.(2013).Psikologi Sastra.Jakarta:Yayasan Pusat Obor Indonesia.

Moerdowo. (1982). Wayang Its Significance In Indonesian Society. Jakarta: PN BALAI PUSTAKA.

Mulyadi Yadi. (2010). Teater Tradisional. Jakarta: Multi Kreasi Satudelapan.

Nasution. (2012).Kurikulum Pengajaran. Jakarta: Bumi Aksara.

Prastowo Andi. (2015).Bahan Ajar Inovatif.Jogjakarta:DIVA Press.

Santrock John W.(2013).Psikologi Pendidikan.Jakarta:Fajar Inter Pratama mandiri.

Siswanto, Roekhan. (2015).Psokologi Sastra.Malang:Media Nusa Creatif. Soetrisno. (2010).Wayang Sebagai Warisan Budaya Dunia.Surabaya:SIC.

Sugiantomas Aan.(2010).Langkah Awal Menuju Apresiasi Sastra.Kuningan: FKIP UNIKU. 
FON ; Jurnal Pendidikan Bahasa dan Sastra Indonesia

Volume 12 Nomor 1 Tahun 2018

Sumardjo Jacob, Saini $\quad$ K.M. Yaniawati Poppy. Indrawan Rully. (2014).

(1988).Apresiasi

Kesusastraan.Jakarta:GRAMEDIA.

Tohari Ahmad.2011.Senyum

Karyamin.Jakarta:Gramedia

Pustaka.
Metodologi

Penelitian.

Bandung:PT. Refika Aditama.

Zubaedi. (2013).Desain Pendidikan

Karakter.Jakarta:KENCANA

PRENANDA MEDIA GRUP. 